Vol 11, Issue 5, 2018

\title{
EVALUATION OF TRACHYSPERMUM AMMI SEEDS FOR ANTIMICROBIAL ACTIVITY AND PHYTOCHEMICAL ANALYSIS
}

\author{
SAGAR BASHYAL, AVIJIT GUHA \\ Department of Biotechnology, IILM College of Engineering and Technology, Greater Noida, Uttar Pradesh, India. \\ Email: sagar.bashyal.bt18@iilmcet.ac.in
}

Received: 26 December 2017, Revised and Accepted: 30 January 2018

\section{ABSTRACT}

Objective: The objective of this study is to identify medicinally important phytochemicals and evaluate the antimicrobial potential of Trachyspermum ammi seeds.

Methods: Four different extracts (methanol, acetone, chloroform, and water) were prepared using a soxhlet apparatus, antimicrobial activity was tested using agar well-diffusion technique.

Results: The results revealed the presence of flavonoids and saponins in all the extracts prepared. Similarly, alkaloids and phenols presence were obtained in methanol and aqueous extracts. Glycosides and carbohydrates in methanol, chloroform, and aqueous extracts. Further, proteins, terpenoids, and tannins presence were found in methanol, chloroform, and aqueous extracts, respectively. The maximum zone of inhibition was found in the methanolic extract $(13.5 \mathrm{~mm})$. Acetone, chloroform, and water extracts showed $9 \mathrm{~mm}, 10.5 \mathrm{~mm}, 11 \mathrm{~mm}$ respectively, while ciprofloxacin (control) showed $17.5 \mathrm{~mm}$ of the zone of inhibition.

Conclusion: T. ammi seeds exert biological properties due to the presence of various chemical constituents. Thus, it can be used to obtain novel antibacterial compounds for the treatment of infectious diseases in the future.

Keywords: Trachyspermum ammi, Seed extracts, Phytochemicals, Antimicrobial activity.

(C) 2018 The Authors. Published by Innovare Academic Sciences Pvt Ltd. This is an open access article under the CC BY license (http://creativecommons. org/licenses/by/4. 0/) DOI: http://dx.doi.org/10.22159/ajpcr.2018.v11i5.24430

\section{INTRODUCTION}

Since from past ages, medicinal plants, also known as medicinal herbs have been discovered and used in traditional medicine practices. The plants that are found naturally are capable to synthesize various chemical compounds for botanical functions that provide defense capability against the number of insects, fungi, diseases, and herbivorous mammals. There is a continuous need for the development of new effective antimicrobial drugs because of the emergence of new infectious diseases and drug resistance [1,2]. In the present scenario, herbal drugs and their formulations have become an alternative to the synthetic drugs [3]. The plant-derived natural products are the products of secondary metabolism; the compounds which are not essential for existence in laboratory conditions, but are certainly responsible for self-defense coordination in natural conditions [4]. Ajwain, Trachyspermum ammi, (L.) sprague ex-belonging to the family Apiaceae is also known as Ajowan caraway, Oomam in Tamil, bishop weeds or carom. T. ammi is mostly found throughout India and is cultivated in Rajasthan and Gujarat. The seeds of T. ammi are native of Egypt and are cultivated in different regions of Iraq, Afghanistan, and India. In India, the seeds are cultivated in Gujarat, Rajasthan, Madhya Pradesh, Uttar Pradesh, Maharashtra, Bihar, and West Bengal. The oil obtained from the seeds exhibits fungicidal [5] antimicrobial [6] and anti-aggregatory effects on humans [7]. It is an important source which acts as a remedial agent for flatulence (gas problem), atonic dyspepsia (indigestion), and diarrhea [8]. An essential oil obtained after the hydrodistillation of the fruits of the plant consists thymol, gammaterpinene, and p-cymene as well as more than 20 trace compounds (predominately terpenoids) [9].

T. ammi has been found to possess the following properties:

- Antimicrobial [10].

- Hypolipidemic: Used for the treatment of high level of fats [11].
- $\quad$ Digestive stimulant [12].

- Antispasmodic: Used for smooth muscle relaxation.

- Bronchodilating: Provide relief from acute bronchoconstriction [13].

- Antihypertensive.

- Hepatoprotective.

- Diuretic: Increases the production of urine [14].

- Abortifacient [15].

- Anti-lithiasis.

- Galactogogic [16].

- Antiplatelet-aggregator [7].

- Anti-inflammatory [17].

- Antitussive: Suppress coughing [18].

- Anti-filarial [19].

- Gastroprotective [20].

- Nematicidal [21].

- Anthelmintic [22].

- Detoxification of aflatoxins [23].

- Ameliorative effects [24].

Therapeutic uses of $T$. ammi fruits include stomachic, expectorant and carminative [25], antiseptic and amoebiasis, and antimicrobial. Although a lot of work has been performed to evaluate the phytochemicals and pharmacological action of these seeds, from the point of ethnomedical claims, nothing has been discovered with regard to T. ammi action over Escherichia coli. Therefore, the current study was aimed to carry out the phytoconstituents testing and to analyze antibacterial activity against $E$. coli using the extracts prepared in the laboratory.

Taxonomic classification [26]

- Kingdom: Plantae, Plant

- Subkingdom: Tracheobionta, Vascular plants 
- $\quad$ Super division: Spermatophyta, Seed plants

- Division: Magnoliophyta, Flowering plants

- Class: Magnoliopsida, Dicotyledons

- Order: Apiales

- Family: Apiaceae

- Genus: Trachyspermum

- Species: Ammi.

\section{METHODS}

Plant material collection and authentication

Ajwain (T. ammi) was obtained from the local market and field of Greater Noida, India. The seeds were verified by Associate Professor Dr. Avijit Guha in the Department of Biotechnology, IILM College of Engineering and Technology. The seeds were dried using an oven and powdered using an electric grinder. The study of plant morphology was done using a simple determination technique, the shape, size, color, and odor.

\section{Preparation of crude extracts}

About $3 \mathrm{~g}$ of coarse seed powder sample in each 4-conical flask $(200 \mathrm{ml})$ was soxhlet with distilled water $(50 \mathrm{ml})$, methanol and water $(7: 3, \mathrm{v} / \mathrm{v})$, chloroform, and acetone (70\%) for $48 \mathrm{~h}$ in the successive mode using a soxhlet apparatus.

Rotary evaporator (Rotavap, Heidolph Labortechnik VV 2000) was taken for further concentration of crude extracts along with the water bath set at $55^{\circ} \mathrm{C}$. The dried extracts obtained was weighed and percentage extracted was calculated which was then transferred to airtight jars and stored at $4^{\circ} \mathrm{C}$ in the refrigerator for the future use. The crude extracts obtained were taken for further investigation of phytochemicals and antimicrobial evaluation.

\section{Equipment's sterilization}

The petri dishes and pipettes packed into metal canisters were appropriately sterilized in the hot air oven at $170^{\circ} \mathrm{C}$ for $1 \mathrm{~h}$ at each occasion. Laminar air flow was cleaned with $70 \%$ ethanol before starting the culturing of microbes.

\section{Maintenance of test organisms}

The E. coli sample was maintained weekly by subculturing on agar slants. Before starting the experiment, the cells were activated by successive subculturing and incubation.

\section{PHYTOCONSTITUENTS ANALYSIS}

The phytochemical tests were carried out for four different extracts as mentioned above using the standard methods [27-30].

\section{Test for alkaloids}

Dragendorff's test

About $1 \mathrm{ml}$ of aqueous extract was taken and stirred properly with the addition of $1 \mathrm{ml}$ of the Dragendorff's reagent. A reddish-brown precipitate confirms that test as positive.

\section{Test for carbohydrates}

Benedict's test

$1 \mathrm{ml}$ of Benedict's solution was added to the concentrated and filtrate aqueous extract obtained by mixing $1 \mathrm{mg}$ of seed extract in $2.5 \mathrm{ml}$ of water and boiled for $5 \mathrm{~min}$. The presence of carbohydrates was identified by the formation of a brick red precipitate.

\section{Test for saponins}

Froth test

About $0.5 \mathrm{mg}$ of the dried seed extracts was added to $3 \mathrm{ml}$ of distilled water and concentrated. The mixture was shaken vigorously for a few minutes. Saponin presence was identified by the formation of foam across the surface for a few minutes.

\section{Test for flavonoids}

\section{Alkaline reagent test}

About 3 ml of aqueous seed extract was added with a few drops of sodium hydroxide solution. Flavonoids presence was identified by the formation of yellow color which in addition of dilute acetic acid disappears.

\section{Test of proteins \\ Biuret test}

About $1 \mathrm{ml}$ of the seed extract solution was taken and $4 \% \mathrm{NaOH}$ solution and $1 \%$ CuSO4 solution were added. Proteins presence was identified by the formation of violet color accordingly.

\section{Test of tannins}

Ferric chloride test

A volume of $3 \mathrm{ml}$ of seed extracts were taken and a few drops of $0.1 \%$ ferric chloride solution were added and allowed to stand for a few minutes. Tannins presence was identified by the formation of brownishgreen or blue-black color.

\section{Tests for steroids and terpenoids}

Salkowski test

$1 \mathrm{ml}$ of each aqueous extract was treated in chloroform with a few drops of concentrated $\mathrm{H}_{2} \mathrm{SO}_{4}$, shaken well and left to stand for a few minutes. After few minutes, steroids presence was identified by formation of red color at the lower layer and terpenoids by the formation of a yellowcolored lower layer.

\section{Tests for glycosides \\ Borntrager's test}

About $3 \mathrm{ml}$ of seed aqueous extract was shaken vigorously. Further, $1 \mathrm{ml}$ of benzene and $1 \mathrm{ml}$ of dilute ammonia solution were added. Glycosides presence was identified by the formation of reddish pink color.

\section{EVALUATION OF ANTIMICROBIAL ACTIVITY}

\section{Test microorganisms and control}

The extracts of the seeds of T. ammi were tested against E. coli. The clinical site was the major source used for the isolation of E. coli cells. The medium for isolation and subculture was sterilized using the wet heat sterilization method. The isolated culture in the nutrient agar medium was subcultured in a nutrient broth and was taken for the incubation, which was kept at the temperature of $37^{\circ} \mathrm{C}$ for $24 \mathrm{~h}$ for. Ciprofloxacin was taken as the control for E. coli cells. Moreover, the zone formation was compared with the control along with the measurement of the length ( $\mathrm{mm})$.

\section{Antimicrobial assay}

Agar well-diffusion method was used to determine the antimicrobial activity. The E. coli suspension was seeded on two Muller Hinton Agar plates which were maintained in the sterilized condition. Using the sterilized corn borer, two wells were punched in each plate. $30 \mathrm{mg}$ of dried crude extract (each) was dissolved in $1 \mathrm{ml}$ of $20 \%$ dimethyl sulfoxide and from the stock solution, using a micropipette $70 \mu \mathrm{l}$ of water extract and control $(100 \mu \mathrm{g} /$ well $)$ was loaded in the first plate (well 1 and 2) and again, the same concentration of acetone, chloroform, and methanol extract was loaded in the second plate in respective numbered wells. Then, plates were incubated for $24 \mathrm{~h}$ at the temperature of $37^{\circ} \mathrm{C}$.

The antimicrobial activity was analyzed using the diameter measurement method of inhibition zone formed around well. The effects were compared with that of the standard antibiotic ciprofloxacin.

\section{RESULTS}

Phytoconstituents screening

Phytochemical test of four different extracts prepared using an Soxhlet apparatus (Fig. 1) is shown in Table 1. Flavonoids and saponins presence was found in all extracts. Alkaloids and phenols presence 
were seen in methanol and aqueous extracts. Alkaloids show a potent antioxidant property. An antioxidant is an important property by which living organisms can neutralize the toxic and cell-damaging the molecules called free radicals, which are produced during various metabolic reactions in the body [31]. Carbohydrates and glycosides presencewere seen in methanol, chloroform, and aqueous extracts. Further, proteins, terpenoids, and tannins presence were found in methanol, chloroform, and aqueous extracts, respectively. Plant terpenoids are used extensively for their aromatic qualities and play a role in traditional herbal remedies [32].

\section{Antimicrobial activity}

After incubation for $24 \mathrm{~h}$ from the time of loading of extracts, inhibition zones were measured. From this process, we came to know that different forms of extracts have different antimicrobial potential. The controlled region showed inhibition zone of $17.5 \mathrm{~mm}$. At a concentration of $70 \mu \mathrm{l}$ taken from the stock solution, the methanolic, acetone, chloroform, and aqueous extracts showed inhibition zone of $13.5 \mathrm{~mm}, 9 \mathrm{~mm}, 10.5 \mathrm{~mm}$, and $11 \mathrm{~mm}$ (Table 2). A maximum zone of inhibition was found in the methanolic extract.

Table 1: Phytochemicals present/absent in seed extracts of T. ammi

\begin{tabular}{llllll}
\hline S.No. & Phytochemicals & Methanol & Acetone & Chloroform & Water \\
\hline 1. & Alkaloids & + & - & - & - \\
2. & Carbohydrates & + & - & + & + \\
3. & Saponins & + & + & + & + \\
4. & Flavonoids & + & + & + & + \\
5. & Proteins & + & - & - & + \\
6. & Tannins & - & - & - & + \\
7. & Steroids & - & - & - & - \\
8. & Terpenoids & - & - & + & - \\
9. & Glycosides & + & - & + & + \\
\hline
\end{tabular}

$(+)$ : Indicates the presence of secondary metabolite, $(-)$ : Indicates the absence of secondary metabolite. T. ammi: Trachyspermum ammi

Table 2: Antibacterial activity of seed extracts of T. ammi

\begin{tabular}{ll}
\hline Solvent extract & Zone of inhibition (mm) \\
\hline Methanolic & $13.5 \pm 0.42$ \\
Acetone & $9 \pm 0.34$ \\
Chloroform & $10.5 \pm 0.20$ \\
Aqueous & $11 \pm 1.2$ \\
Control (ciprofloxacin) & $17.5 \pm 1.33$
\end{tabular}

Inhibitory zones in $\mathrm{mm}$, represented as mean $\pm S D$ values $(n=4)$.

T. ammi: Trachyspermum ammi, SD: Standard deviation

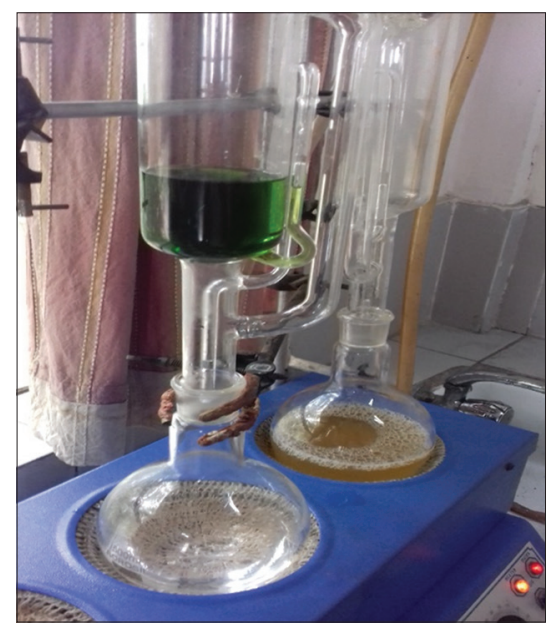

Fig. 1: Soxhlet apparatus

\section{DISCUSSION}

The study reported that most of the constituents required for the purpose of medicinal treatment were found in T. ammi seeds. Ghosh et al. [33] and Kavitha et al. [34] also performed the similar study through which they detected terpenoids, flavonoids, saponins, tannins, and phenolic compounds in different extracts of Polyalthia longifolia, which has a high content of pharmaceutically important plant-based chemicals. Bashyal et al. also performed the phytochemical study on leaves of Calotropis procera where they were able to find constituents such as carbohydrates, saponins, alkaloids, flavonoids, proteins, and tannins [35].

Nowadays, many plants have been discovered having the reservoir of the phytochemicals in the form of secondary metabolites. Various researchers are interested in formulating new drugs using these medicinal sources. Bharathi et al. [36] studied how the medicinal plants have affected the HIV-related opportunistic bacterial and fungal pathogens. From the analysis phytochemicals such as alkaloids, carbohydrates, flavonoids, saponins, tannins, terpenoids, and glycosides were found

Many studies have pointed to the antioxidant properties of the medicinal plants. Flavonoid has the capability of acting as antioxidant property. Alkaloids bear the anticancer property. The seed extracts were also revealed to have saponins, which are known to produce the effect on inflammation [37]. Plant-source rich in phytochemicals not only show antibacterial action to few bacteria's but to a large number of Gram-positive and Gram-negative bacteria. A recent study shows that T. ammi seeds have the potential insecticidal activity [38] to Tribolium castaneum. Other plants that show similar actions to the T. ammi seeds are Anethum graveolens and Nigella sativa.

\section{CONCLUSION}

The study revealed that the seeds of T. ammi have potent antimicrobial activity and can be used for pharmacological evaluation, drug discovery, and treatment of various infectious diseases. We found that the seeds contain alkaloids, carbohydrates, glycosides, flavonoids, proteins, terpenoids, tannins, and phenols which have the high medicinal purpose. The high zone of inhibition was seen in the methanolic extract which signifies the high antimicrobial action than other three extracts. This medicinal plant needs a scientific exploration of the hidden curative and therapeutic potential.

\section{ACKNOWLEDGMENT}

The authors are thankful for the Head, Department of Biotechnology, IILM College of Engineering and Technology, Greater Noida, for providing necessary laboratory facilities to conduct this research work.

\section{AUTHORS CONTRIBUTION}

Sagar Bashyal carried out the experiment, wrote the manuscript along with the support and supervision of Associate Professor Dr. Avijit Guha. Both authors conceived the original idea.

\section{CONFLICT OF INTEREST}

The authors declare that no conflict of interest occurred during the work.

\section{REFERENCES}

1. Lenski RE. Bacterial evolution and the cost of antibiotic resistance. Int Microbiol 1998;1:265-70.

2. Raghunath D. Emerging antibiotic resistance in bacteria with special reference to India. J Biosci 2008;33:593-603.

3. Patel I, Talathi A. Use of traditional Indian herbs for the formulation of shampoo and their comparative analysis. Int J Pharm Pharm Sci 2016;8:28-32.

4. Adhikari P, Paul S. History of Indian traditional medicine: A medical inheritance. Asian J Pharm Clin Res 2018;11:421-6. 
5. Singh I, Singh VP. Antifungal properties of aqueous and organic extracts of seed plants against Aspergillus flavus and A. niger. Phytomorphology 2000;20:151-7.

6. Sivropoulou A, Papanikolaou E, Nilolaou C, Kokkini S, Lanaras T, Arsenakis M. Antimicrobial and cytotoxic activities of origanum essential oils. J Agric Food Chem 1996;44:1202-5.

7. Srivastava KC. Extract of a spice-Omum (Trachyspermum ammi)shows antiaggregatory effects and alters arachidonic acid metabolism in human platelets. Prostaglandins Leukot Essent Fatty Acids 1988;33:1- 6 .

8. Bentely R, Trimen H. Medicinal Plants. New Delhi: Asiatic Publishing House; 1999. p. 107-15.

9. Singh G, Maurya S, Catalan C, De Lampasona MP. Chemical constituents, antifungal and antioxidative effects of ajwain essential oil and its acetone extract. J Agric Food Chem 2004;52:3292-6.

10. Bonjar GH. Anti-yeast activity of some plants used in traditional herbalmedicine of Iran. J Biol Sci 2004;4:212-5.

11. Kumari KS, Prameela M. Effect of incorporating Carum copticum seeds in a high fat diet for albino rats. Med Sci Res 1992;20:219-20

12. Vasudevan K, Vembar S, Veeraraghavan K, Haranath PS. Influence of intragastric perfusion of aqueous spice extracts on acid secretion in anesthetized albino rats. Indian J Gastroenterol 2000;19:53-6.

13. Gilani AH, Jabeen Q, Ghayur MN, Janbaz KH, Akhtar MS. Studies on the antihypertensive, antispasmodic, bronchodilator and hepatoprotective activities of the Carum copticum seed extract. J Ethnopharmacol 2005;98:127-35.

14. Ahsan SK, Shah AH, Tanira MO, Ahmad MS, Tariq M, Ageel AM. Studies on some herbal drugs used against kidney stones in Saudi folk medicine. Fitoterapia 1990;61:435-8.

15. Nath D, Sethi N, Srivastav S, Jain AK, Srivastava R. Survey on indigenous medicinal plants used for abortion in some districts of Uttar Pradesh. Fitoterapia 1997;68:223-5.

16. Kaur H. Estrogenic activity of some herbal galactogogue constituents. Indian J Anim Nutr 1998;15:232-4.

17. Thangam C, Dhananjayan R. Antiinflammatory potential of the seeds of Carum copticum Linn. Indian J Pharmacol 2003;35:388-91.

18. Boskabady MH, Jandaghi P, Kiani S, Hasanzadeh L. Antitussive effect of Carum copticum in guinea pigs. J Ethnopharmacol 2005;97:79-82.

19. Mathew N, Bhattacharya SM, Perumal V, Muthuswamy K. Antifilarial lead molecules isolated from Trachyspermum ammi. Molecules 2008;13:2156-68.

20. Ramaswamy S, Ramaswamy S, Sengottuvelu S, Sherief SH, Jaikumar S, Saravanan R, et al. Gastroprotective activity of ethanolic extract of Trachyspermum ammi fruit. Int J Pharm Biosci 2010;1:1-15.

21. Pelczar MJ, Chan EC, Krieg NR. Control of Microorganism by Physical Agents, in Microbiology. New York: Mcgraw Hill International; 1988. p. 469-509.

22. Priestley CM, Williamson EM, Wafford KA, Sattelle DB. Thymol, a constituent of thyme essential oil, is a positive allosteric modulator of human GABAA receptors and a homo oligomeric GABA receptor from Drosophila melanogaster. Br J Pharmacol 2003;140:1363-72.

23. Velazhahan R, Vijayanandraj S, Vijayasamundeeswari A, Paranidharan V,
Samiyappan R, Iwamoto T, et al. Detoxification of aflatoxins by seed extracts of the medicinal plant, Trachyspermum ammi (L.) Sprague ex turrill structural analysis and biological toxicity of degradation product of aflatoxin G1. Food Control 2010;21:719-25.

24. Anilakumar KR, Saritha V, Khanum F, Bawa AS. Ameliorative effect of ajwain extract on hexachlorocyclohexane-induced lipid peroxidation in rat liver. Food Chem Toxicol 2009;47:279-82

25. Chialva F, Monguzzi F, Manitto P, Akgül A. Essential oil constituents of Trachyspermum copticum (L.) link fruits. J Essent Oil Res 1993;5:105- 6

26. Choudhury S, Riyazuddin A, Kanjilal PB, Leclercq PA. Composition of the seed oil of Trachyspermum ammi (L.) Sprague from Northeast India. J Essent Oil Res 1998;10:588-90.

27. Mamta S, Jyoti S. Phytochemical screening of Acorus calamus and Lantana camara. Int Res J Pharm 2012;3:324-6.

28. Parihar S, Kartik DV, Pithawala EA, Shukla MD, Lahiri SK, Jain NK, et al. Phytochemical screening, total phenolic content, antibacterial and antioxidant activity of wild edible mushroom Pleurotus ostreatus. Int Res J Pharm 2015;6:65-9.

29. Mumtaz F, Massod RS, Zubair A, Iftikhar A, Musaddique H. Qualitative phytochemical analysis of some selected medicinal plants in local area of Faisalabad Pakistan. J Pharm Altern Med 2014;3:17-23.

30. Reddy S, Ch A, Mary KR, Rajesh TN, Aravind G, Ch BS. Phytochemical and GC-MS analysis of Commiphora caudata (Wt\&Arn.) Eng. Bark. Indian J Adv Plant Res 2014;1:24-9.

31. Swargiary A, Nath P, Basumatary B, Brahma D. Phytochemical, antioxidant, and trace element analysis of anthelmintic plants of northeast India. Int J Pharm Pharm Sci 2017;9:228-32.

32. Sakthi A. Preliminary phytochemical screening and in-vitro free radical scavenging activity of root extracts of Glycyrrhiza glabra L. Asian J Pharm Clin Res 2016;9:85-90.

33. Ghosh G, Subudhi BB, Badajena LD, Ray J, Mishra MK, Mishra SK. Antibacterial activity of Polyalthia longifolia var. Angustifolia stem bark extract. Int J PharmTech Res 2011;3:256-60.

34. Kavitha PA, Pawan K, Narasimah MT, Gopinath SM. Antibacterial activity of Polyalthia longifolia against hospital isolates of Bengaluru district. Int J Latest Res Sci Tech 2013;2:508-10.

35. Bashyal S, Rai S, Abdul O, Hashmi F, Guha A. Preliminary phytochemical testing and antimicrobial activity of Calotropis procera leaves. Int J Trend Sci Res Dev 2017;2:926-30.

36. Bharathi B, Dhanabal M, Perumal A, George SD. Studies on the antibacterial activity and phytochemical screening of Tylophora indica Linn on opportunistic bacterial pathogens coinfected with HIV. Drug Invent Today 2010;2:402-4.

37. Just MJ, Recio MC, Giner RM, Cuéllar MJ, Máñez S, Bilia AR, et al. Anti-inflammatory activity of unusual lupane saponins from Bupleurum fruticescens. Planta Med 1998;64:404-7.

38. Chaubey MK. Insecticidal activity of Trachspermum ammi (Umbelliferae), Anethum graveolens (Umbelliferae) and Nigella sativa (Ranunculaceae) essential oils against stored-product beetle Tribolium castaneum herbst Coleoptra: Tenebrionidae. Afr J Agric Res 2007;2:596-600 